\title{
SEBLANG DAN KENDURI MASYARAKAT DESA OLEHSARI: Relasi Ideal Antara Islam dan Budaya Jawa di Banyuwangi
}

\author{
Ahmad Kholil \\ Fakultas Humaniora dan Budaya UIN Maulana Malik Ibrahim Malang. Jalan Gajayana No. 50 Malang. \\ Telp. 0341-551354, 081807765237. e-mail: Khumi_01@yahoo.co.id
}

\section{Abstract}

Desa mawa cara negara mawa tata, a Javanese wisdom which means that each place in this country has its own different manner and rules as the essence of its people's cultures and traditions. This paper aims to describe one of Indonesian cultural richness which is transformed in the religious ritual named Seblang in a small village called Olehsari, in Banyuwangi, East Java. This ritual has a religious orientation as an aspiration to the Almighty in order to gain success in agriculture, occupation, and other objectives in the lives of the people of Olehsari. Likewise, Kenduri is also meant as a supplication to the Almighty in order to obtain blessings for the livings and forgiveness for the deceased. In Olehsari, people call this kind of ritual as Ngirim Duwa, or literally translated as 'sending the prayers'. Furthermore, Seblang and Kenduri have certain social purposes to achieve a serene and harmonious living atmosphere for the people.

Key words: seblang, kenduri, Olehsari, religious ritual 


\section{Pendahuluan}

Hampir seluruh masyarakat muslim khususnya di Jawa memiliki kesadaran sejarah dan budaya yang cukup baik. Kesadaran itu tercermin dari sikap sosial keberagamaannya yang mengakomodasi tradisi dan budaya lokal warisan leluhur. Contoh umum untuk hal ini adalah tradisi kenduri atau selamatan untuk berbagai peristiwa yang dianggap perlu penghormatan khusus, misalnya hal-hal yang berhubungan dengan kelahiran, pernikahan bahkan juga kematian. Selain hal tersebut, peristiwa lain yang dianggap mempunyai nilai khusus dalam perjalanan kehidupan manusia juga diiringi dengan kenduri, misalnya menempati rumah baru, hendak melakukan perjalanan jauh, mendapat anugerah berupa rezeki atau pekerjaan, memulai cocok tanam, dan lain sebagainya.

Tidak berbeda dengan daerah lain di Jawa, Banyuwangi juga kaya dengan warisan budaya leluhur yang masih tetap terpelihara dengan baik. Selamatan Desa (baca: slametan deso) yang selalu diadakan setiap tahun sekali di seluruh pedesaan dan kelurahan di Banyuwangi cukup kuat disebut sebagai contoh untuk hal ini. Pada tradisi selamatan desa, masingmasing wilayah memiliki cara yang khas dalam tata cara pelaksanaannya. Desa Grogol Kecamatan Giri misalnya, menyelenggarakan selamatan desa dengan tontonan tradisional yang didahului dengan doa bersama di atas makam leluhur yang dilanjutkan dengan ider bumi (keliling kampung) di malam harinya. Desa Boyolangu di Kecamatan yang sama melakukan doa dan makan bersama di dekat jalan menuju makam umum. Demikian juga malamnya, setelah maghrib warga berkeliling kampung dengan mengumandangkan azan di setiap persimpangan jalan. Tata cara yang serupa juga terjadi di wilayah Kecamatan Giri yang lain seperti Penataban, Jambesari dan Kelurahan Giri.

Sedikit berbeda dalam menghormati leluhur yang telah berjasa membuka lahan untuk pertanian dan permukiman adalah Desa Alasmalang, Bakungan, Kemiren dan Olehsari. Di Desa Alas Malang, selamatan desa dilakukan dengan mengadakan atraksi kebo-keboan, yaitu beberapa orang dirias seperti kerbau untuk kemudian diarak mengelilingi desa dengan membawa uba rampe dari hasil pertanian. Arak-arakan juga dilakukan warga masyarakat Kemiren dalam tradisi selamatan desa, hanya saja di sini mereka berjalan mengelilingi desa mengiringi barong. Adapun di Desa Bakungan dan Olehsari, selamatan itu dilakukan dengan menggelar atraksi seblang. 
Perbedaan di kedua desa ini hanya pada pelaku dan waktunya, kalau di Bakungan yang menjadi penari seblang adalah perempuan tua yang telah cukup umur, sementara di Desa Olehsari adalah perempuan yang masih remaja. Di Desa Bakungan hanya semalam, sedang di Desa Olehsari selama tujuh hari. Seluruh ritual budaya ini selain sebagai wujud ekpresi keberagamaan juga menandakan dekatnya masyarakat dengan alam kehidupannya.

Tulisan ini fokus terhadap pembahasan selamatan desa dengan tradisi seblang di Desa Olehsari. Orbitasi desa ini terletak pada 9 kilo meter dari pusat pemerintahan kota. Desa ini masuk dalam wilayah Kecamatan Glagah dan dari kantor Kecamatan hanya berjarak $3 \mathrm{~km}$. Disamping membahas seblang yang menjadi tradisi tahunan masyarakat Desa Olehsari, penulis juga akan mengungkapkan falsafah yang ada di balik tradisi kejawen yang lain, yaitu kenduri. Ketertarikan penulis pada fenomena seblang dan kenduri ini karena keduanya inheren dalam diri penulis. Sebagai bagian dari tradisi tersebut, dari sudut tourism, penulis merasa berkewajiban mempromosikan seblang ke khalayak agar kondang. Sementara dari sudut keagamaan, agar tidak muncul tuduhan "musyrik" terhadap orang-orang muslim yang memiliki sensitivitas budaya serupa.

Seblang ataupun upacara selamatan desa yang lain mengandung semangat religius yang khas, karena pada dasarnya seblang adalah usaha meminta kepada Yang Maha Kuasa untuk kesuburan tanah, panen melimpah, dan terhindar dari segala macam malapetaka. Tulisan ini diawali dengan pembahasan praktik keberagamaan masyarakat Desa Olehsari. Selanjutnya tentang tradisi seblang dan fungsinya menurut kepercayaan setempat. Terakhir, sebelum penutup penulis akan berbicara mengenai selamatan atau kenduri dan interpretasinya secara filosofis dan kultural.

\section{Praktik Keberagamaan Masyarakat}

Kodrat sebagai manusia memiliki pengetahuan dan daya nalar yang terbatas. Keterbatasan itu memaksa manusia untuk mengakui dan menerima hal-hal yang di luar jangkauannya. Atas dasar keterbatasan itu lahirlah agama yang dikatakan sebagai ekspresi ketidakmampuan manusia untuk menangkap atau menerangkan dengan akal pikiran gejala-gejala yang ada di alam. Pada sisi yang lain, agama juga bisa muncul akibat adanya krisiskrisis yang membuat gelisah dalam kehidupan manusia. Ia ingin kegelisahan itu hilang dan menemukan agama sebagai jawabannya. Karena itu James 
Martineau mengartikan agama sebagai keyakinan dalam hati terhadap kekuatan maha dahsyat yang mengatur alam semesta (Rahmat, 2005: 21).

Adapun hal-hal yang mendorong manusia untuk melaksanakan aktivitas-aktivitas yang bersifat keagamaan di antaranya adalah karena adanya emosi dan getaran jiwa yang sangat mendalam yang disebabkan rasa takut, terpesona pada sesuatu yang gaib dan keramat, di samping juga adanya harapan-harapan yang mengiringi perjalanan kehidupannya (Muthahhari, 2007: 103). Perasaan-perasaan itu terpancar dari daya misterius yang merupakan prinsip penyatuan dengan alam semesta. Pada masyarakat primitif, orang mengaitkan perasaan-perasaan itu dengan sejenis binatang atau tumbuhan yang dimaksudkan untuk ikut serta ambil bagian dalam sifat misteri yang dijelmakan pada jenis binatang atau tumbuhan tersebut (Veeger, 1993: 157).

Sementara itu, pada masyarakat yang masih dalam masa transisi dari tradisi lama yang telah melekat menuju tradisi baru yang asing seringkali terjadi dualisme ekspresi yang tampak berlawanan. Dualisme ekspresi itu bisa disaksikan dalam kehidupan sehari-hari masyarakat Desa Olehsari. Pada satu sisi, mereka mengakui kebenaran yang tersimpul dari ajaran-ajaran Islam dan mengamalkannya sebagaimana yang diperintahkan. Sementara pada sisi yang lain, mereka tetap mempercayai hal-hal yang berhubungan dengan tradisi warisan budaya Hindu-Budha. Kedua sikap yang berlawanan itu muncul dalam praktik keberagamaan dan upacara seblang yang hingga kini masih eksis dengan pemaknaan yang berbeda di tengah masyarakat.

Kajian Islam normatif di Jawa pada umumnya hanya memusatkan perhatian pada muslim perkotaan dan kaum modernis, atau Islam tradisional yang dianggap mewakili ortodoksi dengan mengabaikan Islam sebagaimana dipraktikkan sehari-hari di pedesaan. Dalam kajian yang telah ada, mereka yang mafhum dan memiliki artikulasi yang kuat dengan kedudukan dan posisi ideologis yang dapat diformalisasikan secara jelas dalam kehidupan keseharian masyarakat kurang diperhatikan. Dalam praktik keberagamaan masyarakat, pemisahan agama santri dan nonsantri, seperti uraian Geertz yang membagi pandangan keagamaan Jawa dalam tiga varian; santri, abangan dan priyayi, mengesankan bahwa praktisi ketiganya konsisten pada identitas masing-masing. Padahal sebenarnya sebagaimana diketahui, banyak pedesaan Jawa yang dihuni oleh komunitas heterogen, dan banyak individu dalam komunitas tersebut tidak jelas posisinya, santri, 
nonsantri, atau berada di antara keduanya.

Di daerah tengah ini santri hidup berdampingan dengan abangan, suatu gejala yang ingin dibahas, suatu wilayah kompromi, tidak konsisten, dan ambivalen yang tidak dapat ditangkap oposisi kategorial santri versus abangan. Dikalangan orang Using dan imigran Jawa di daerah Banyuwangi, tidak ada perbedaan besar antara santri dan yang lain berkaitan dengan praktik keberagamaan, terutama mengenai selamatan. Fakta sosial menunjukkan, banyak lulusan pesantren atau hanya lulusan sekolah umum saja bersama-sama mempelajari doa atau bacaan-bacaan tertentu demi keselamatan ataupun untuk sekedar selamatan melalui buku-buku doa atau bertanya pada orang yang dianggap tahu tentang agama.

Barangkali dikotomi atau trikotomi yang diuraikan Geertz terlalu kasar jika diterapkan dalam kerangka analisis. Oleh karena itu, rasanya diperlukan kategori-kategori standar yang menemukan bayang-bayang majemuk yang kelabu di antara tipe-tipe tersebut. Tetapi kompleksitas peradaban Jawa terletak tidak hanya pada kemajemukan, melainkan juga pada keterkaitan hubungan dalam dinamika adaptasi agama dan perubahan. Penjumlahan kategori bukannya memperjelas melainkan menjadikan kategori-kategori itu kabur. Keterkaitan hubungan dapat dipahami dalam konteks kondisi lokal, bukan dalam pengertian tipe atau kategori ideal yang menurut definisi justru menjauhi kompromi dari realitas sosial. Dalam kenyataan sosial, santri konservatif seringkali memiliki banyak persamaan dengan abangan dibandingkan dengan santri modernis.

Golongan konservatif seolah setengah berjanji dengan tradisi abangan, sehingga membuat kedua golongan ini mengembangkan kebudayaan sebagaimana yang ada pada masa transisi, yaitu zaman peralihan dari HinduBudha ke Islam. Model interaksi yang demikian lebih memudahkan dalam berkomunikasi dan dapat terhindar dari ketegangan seperti yang mungkin terjadi antara orang yang benar-benar Islam dan yang benar-benar kejawen penganut mistik.

Pemahaman muslim tradisional di desa menekankan bahwa agama dan adat-istiadat saling melengkapi, sehingga di antara keduanya tidak ada perbedaan, kalaupun ada sifatnya kabur. Puasa misalnya, dilihat sebagai kewajiban agama sekaligus juga adat. Seperti orang yang beragama karena keturunan (prescribed prayer), puasa memberikan manfaat kejawaan seperti ketenangan batin, keamanan, dan penguasaan diri. Manfaat ini menjadi 
pembenaran yang cukup signifikan bagi pelaksanaan ritual semacam puasa. Oleh karena itu, demi kerukunan tidak perlu masuk secara lebih dalam ke substansi otoritas skriptural.

Ritualisme pragmatik semacam ini tentu saja terbuka bagi kritik dari sudut pandang yang lain. Dalam pandangan mistik yang reflektif, falsafah yang demikian itu terwujud dalam upacara ritual sederhana yang disebut selamatan atau kenduri. Penekanan pada aturan dan teknik yang kehilangan makna akan menjadikan ritual itu tanpa tujuan, bahkan tidak memberikan efek kejiwaan sama sekali. Sebagaimana dikenal, golongan mistik menguraikan perilaku keagamaan pada tahapan-tahapan seperti sarengat dan hakekat, kebenaran mendasar atau makna esoteris. Karena itu, bentuk luar dianggap sebagai inferior bagi makna bagian dalam, akibatnya muslim kejawen yang taat tidak pernah mempersoalkan aturan-aturan baku syari'at (Simuh, 1989: 161).

Jika dalam masalah keberagaman sekarang ini ada komentar-ko-mentar yang mengatakan bahwa muslim tradisional biasa yang taat terjepit di antara reformis, yang menyingkirkan semua adat yang bukan Islam dan mistik, dalam kenyataannya tidak demikian. Muslim Using Desa Olehsari, dengan simpati modernis yang masih minoritas jarang menyatakan pendapat di depan publik, dan muslim tradisional (kejawen), telah lama menjalin hubungan baik yang amat harmonis dengan membatasi kritik pedas satu sama lain.

Dari sini ditegaskan bahwa Islam normatif di masyarakat Using pedesaan dipandang sebagai praktik dan hampir tidak berisi doktrin. Bagi orang yang taat, yang melaksanakan sembahyang lima kali sehari semalam, melaksanakan puasa penuh, selalu berdzikir di tempat peribadatan atau di manapun, Islam adalah suatu sistem preskripsi ritual di samping juga sistem kepercayaan yang koheren dan eksplisit. Di tengah masyarakat yang demikian, bila di antara mereka ada orang yang ingin membicarakan doktrin, orang akan dengan cepat melemparkannya ke aksioma yang tak dapat diganggu gugat dan spekulasi idiosinkretik. Setelah itu dengan cepat kembali lagi ke praktik sosial yang lebih konkrit tanpa harus mengiringinya dengan pengetahuan "skriptif" secara lebih detil.

\section{Upacara Seblang}

Seblang adalah sebuah pertunjukan ritual keagamaan tahunan yang diadakan masyarakat Desa Olehsari sebagai persembahan agung untuk 
selamatan desa. Sebagai acara ritual, tentu memiliki aturan dan tata cara tersendiri yang meliputi; waktu, tempat, pelaku (terutama penari), dan yang tidak boleh ketinggalan adalah sajen (sesaji). Seiring perjalanan waktu, apa yang dulu menjadi otoritas segelintir orang kini telah menjadi sesuatu yang perlu pembahasan dan musyawarah bersama dengan melibatkan banyak pihak, apalagi ia telah menjadi komoditas sosial-ekonomi dan budaya desa. Apa yang akan diuraikan berikut adalah proses dan tata cara yang tak pernah luput dari rembug bersama baik dikalangan makhluk kasar (panitia, aparat desa dan masyarakat) maupun dengan kalangan roh halus para leluhur melalui mediator orang yang dianggap masyarakat bisa berkomunikasi dengan mereka.

\section{Tata Cara Upacara}

Proses upacara seblang di Desa Olehsari mempunyai ciri khas dan ketentuan tersendiri. Ciri khas pertama yaitu waktu pelaksanaan ada ketentuannya dan terpilih. Hari pelaksanaan upacara selalu ditentukan pada hari Senin atau Jum'at di awal bulan Syawal. Pelaksanaannya antara jam 14.00 sampai kira-kira jam 16.30 WIB. Menurut informasi, dulu acara ini dilaksanakan pada awal tahun Hijriyah (Suro-Jawa), kemudian atas petunjuk bisikan leluhur dirubah pada bulan Syawal (Sutarto, 2006: 3).

Upacara ritual ini dilaksanakan sepekan berturut-turut dan setelah upacara selesai dalam satu pekan, tepatnya pada hari kedelapan, para pendukung yang dalam hal ini pesinden, penari dan ibunya harus melakukan siraman dengan maksud mengembalikan para roh yang menempel di jasad ke alam asalnya. Kemudian setelah semuanya usai, baru mereka bersama tetangga sekitar lokasi siraman melakukan selamatan dengan doa bersama dengan cara-cara Islami.

Ketentuan yang kedua mengenai lokasi upacara. Lokasi penyelenggaraan upacara seblang harus diadakan di Desa Olehsari, tidak boleh dan tidak bisa dilaksanakan di luar. Dalam hal ini masyarakat setempat selalu teringat peristiwa 80-an yang mementaskan seblang di kota Banyuwangi. Akibatnya, sang penari tak mau sadarkan diri hingga pagi hari. Berhubungan dengan masalah lokasi, tempat ritual harus menghadap ke timur dan harus ada bangunan kecil yang disebut tarub. Selain itu ada tempat duduk khusus bagi penari dan pesinden yang berada sedikit di belakang payung besar yang disebut payung agung. Pada acara ini, tepatnya di hari terakhir penari 
bersama seluruh pendukung acara harus berputar mengelilingi desa sambil menari, kemudian berhenti di balai desa, berjalan dan berhenti lagi di makam Mbah Bisu, dilanjutkan menari sambil terus berjalan sampai ke lokasi awal pemberangkatan.

Ketentuan ketiga berkaitan dengan pelaku upacara, lebih khusus penari. Dalam ritual seblang ini, para pelaku harus dipilih dan ditentukan menurut adat yang berlaku. Pemimpin upacara dipilihkan orang yang dianggap mampu memimpin jalannya upacara. Saleh (Mbah Saleh) adalah dukun khusus di Desa Olehsari yang dipercaya oleh masyarakat menjadi pimpinan, yaitu untuk ngutugi dan mengundang roh halus. Dalam pertunjukan tari, Saleh selalu membawa prapen (tempat untuk membakar kemenyan atau anglo) dan mengunyah kemenyan, kemudian ia mengasapi penari sebagai santapan dan minumannya, caos dhahar, katanya.

Selain sebagai pengutug, Saleh juga sebagai pengundang. Maksudnya, ia selain bertanggungjawab dalam upacara juga bertanggung jawab pada masalahmasalah yang berkaitan dengan roh halus terutama ketika pertunjukan tari akan dimulai dan diakhiri. Sebelum penari melakukan gerak tari, terlebih dahulu dilakukan acara ngundang roh halus supaya merasuk ke sukma penari seblang. Saat ngutugi untuk mengundang roh ini ada mantra yang dibaca sebagai berikut:

Kang Ana Ring Pecemengan Sembulungan

Kang Ana Ring Bali Anggenan

Kang Ana Ring Watudodol

Kang Ana Ring Antogan Ring Weringin

Mbah Jalil, Buyut Ketut, Para Alus

Kang Petang Pucuk Papat Tekoho Merene, Mbah Jalil Gandrungan

Aji Anggring, Buyut Saridin, Kang Ana Ring Kawah Ijen Sang Pengutug

Mereneyo Dianteni Ring Pendopo Agung (Saleh, Wawancara: 14 September 2010).

Berkaitan dengan penari seblang, tidak bisa sembarangan anak bisa dipilih. Penari harus mempunyai garis keturunan dari seorang penari seblang. Garis keturunan itu bisa dari ibu atau bapak yang penting memiliki darah dari para sesepuh ritual ini. Adapun kesucian, yang berarti belum pernah menstruasi, atau belum pernah bersuami, pada masa sekarang ini bukan menjadi masalah. Terbukti beberapa kali penari seblang justru terpilih dari 
seorang janda yang masih muda. Pelaku yang lain seperti pembuat omprok, perias, penabuh, dan pendamping penari adalah orang-orang khusus yang dipilih dengan dasar adat masyarakat Desa Olehsari. Orang-orang tersebut, selain mempunyai skill bidang masing-masing, juga masih ada jalinan keluarga dengan para sesepuh yang merupakan pelaku upacara seblang terdahulu. Ketentuan lain, mereka harus berdomisili di Desa Olehsari.

Tata cara dan ketentuan lain yang juga merupakan ciri khas sebuah upacara ritual adalah sajen. Dalam ritual selamatan desa yang setiap tahun sekali diselenggarakan ini, sajen merupakan syarat pokok yang tidak boleh ditinggalkan. Untuk menyediakan sajen ini, sehari sebelum pelaksanaan upacara sudah harus dipersiapkan lebih dulu mengingat banyaknya sajen dan aneka ragamnya uba rampe yang harus disajikan.

Berbagai macam sajen dalam acara ritual seblang harus ada dan tidak boleh terlewatkan. Macam sajen tersebut adalah sajen buangan, yang artinya sajen tersebut dibuang atau dihantarkan ke tempat-tempat keramat seperti di sumber mata air dan pemakaman. Sajen buangan ini diteliti dan dimantra-mantrai oleh sang dukun sebelum upacara berlangsung. Sajen ini terdiri dari: kembang telon, yang terdiri dari bunga kantil, kenanga dan mawar. Sajen ini juga berupa kepala ayam, brutu ayam, jeroan, sayap dan kaki ayam. Di samping itu, sajen-sajen tersebut disertai pula ragi kuning dan air dalam cangkir atau gelas kecil.

Sajen kedua berupa buah-buahan (rujakan) dan kinangan. Jenisnya berupa jambu, kedondong, nanas, mentimun, belimbing, jeruk, pisang mas, rambutan, manggis, buah sirsat dan air dalam kendi, sedangkan kinangan berupa wadah kinangan dan perabotnya. Sajen ini ditempatkan pada tempat yang telah ditentukan yaitu di bawah atap atau di atas tempat duduk pesinden. Sajen ketiga disebut sajen peras yang terdiri dari; satu buah kelapa yang telah dikupas kulitnya, dua tangkep pisang raja, satu tangkep gula jawa, dan ragi kuning. Sajen ini penempatannya di bawah payung agung atau di bawah gong. Sajen peras, sajen rujakan, dan sajen kuningan semuanya disebut sajen cawisan.

Selain dari sajen-sajen tersebut di atas, masih ada sajen yang harus disajikan di tarub. Sajen tersebut berupa buah-buahan, biji-bijian, sayursayuran, obat-obatan tradisional (empon-empon), dan bunga-bungaan. Semua itu digantung di atas pesinden atau tergantung pada atap tarub. Sajen ini biasa disebut dengan para bungkil. Sajen-sajen itu semua nantinya 
diperebutkan oleh penonton maupun para pelaku setelah acara selesai. Hal ini dimaksudkan sebagai ngalap berkah atau ngelorot dari benda-benda yang dipakai dalam upacara (Saleh, Wawancara: 14 September 2010).

\section{Fungsi Seblang Pada Masyarakat}

Sepanjang perjalanan sejarah, kehidupan seni sebagai bagian dari kebudayaan tidak pernah luput dari perubahan. Perubahan itu terjadi mungkin karena perkembangan pola pikir dan pemahaman manusia terhadap alam dan apa yang ada di sekitarnya, atau mungkin karena gesekan-gesekan dengan unsur lain yang ada di luar dirinya. Dengan demikian, tanpa adanya gangguan yang ditimbulkan oleh masuknya unsur budaya asing sekalipun suatu kebudayaan dalam suatu masyarakat bisa berubah. Sejalan dengan bergulirnya waktu, maka seni pun hanyut dalam pasang surutnya dinamika budaya.

Memang seni sendiri, dalam berbagai wujud pengekspresiannya dapat dijadikan sebagai cermin budaya, karena ia selalu bergerak bersama dengan hati masyarakatnya. Jenis-jenis kesenian dalam konteks kemasyarakatan mempunyai kelompok-kelompok pendukung tertentu dengan fungsi yang berbeda-beda. Ada yang berfungsi hanya sebagai hiburan tanpa memiliki nilai religi, tetapi ada juga yang bernilai religi, dalam artian pelaksanaannya disertai dengan suatu keyakinan atau kepercayaan tertentu.

Kesenian seblang adalah salah satu contoh kesenian yang dipercaya bernilai sakral di masyarakat Using Desa Olehsari dan merupakan warisan budaya praHindu. Salah satu cirinya adalah kepercayaan manusia kepada makhluk halus dan kekuatan supranatural untuk mengendalikan sesuatu dengan menggunakan sarana religi (Koentjaraningrat, 1984: 237). Upacara seblang bagi masyarakat Desa Olehsari merupakan sarana komunikasi dengan Tuhan maupun dengan leluhurnya. Dengan demikian kesenian ini di samping membawakan pesanpesan yang kaitannya dengan religi juga dalam tata hubungan atau pergaulan antar sesama.

Setelah mengamati dengan teliti dan mengadakan wawancara secara mendalam dengan warga sekitar, para pendukung maupun dengan para budayawan Using, serta mengikuti aktivitas-aktivitas selama persiapan, pelaksanaan, sampai menjelang paripurnanya kegiatan ritual tahunan seblang ini, penulis ingin menjelaskan fungsi ritual ini bagi masyarakat pendukungnya. Fungsi-fungsi yang ada pada seblang menurut keyakinan warga adalah sebagai: 


\section{a. Selamatan Bersih Desa}

Dalam selamatan bersih desa, seperti tercermin dari namanya, seluruh warga desa ikut terlibat. Bersih desa atau bersih dusun dilakukan sekali dalam setahun, yaitu pada bulan sela atau syawal dalam kalender Hijriyah. Selamatan desa ini di samping sebagai tradisi yang telah popu-ler di tanah Jawa juga merupakan tradisi tahunan masyarakat Using yang masih terpelihara dengan baik. Pelaksanaannya setiap desa punya waktu yang berbeda-beda. Untuk acara yang sejenis seblang ini, bisa di lihat di Bakungan Desa Mojopanggung Kecamatan Giri pada bulan Dzul Hijjah. Dalam melakukan bersih desa, secara spiritual masyarakat membersihkan diri dari kejahatan, dosa, dan segala yang menyebabkan kesengsaraan. Hal ini tercermin dari berbagai aspek dari perayaan yang diselenggarakan berkenaan dengan upacara tersebut. Di samping itu, ritual ini atau upacara seblang juga menandakan adanya sisa-sisa adat penghormatan terhadap roh nenek moyang (Koentjaraningrat, 1984: 374).

Tradisi upacara bersih desa dalam masyarakat Jawa merupakan upacara yang sangat penting dan bersifat keramat. Upacara keramat seringkali mempunyai prosesi yang tidak sederhana dan tentu saja membutuhkan biaya yang lebih besar daripada upacara selamatan biasa di dalam kehidupan masyarakat desa. Upacara yang sifatnya keramat menurut Koentjaraningrat adalah upacara selamatan di mana orang merasakan getaran emosi keramat, terutama pada waktu menentukan diadakannya selamatan itu, juga waktu upacara berjalan. Keputusan untuk mengadakan suatu selamatan kadangkadang diambil berdasarkan suatu keyakinan keagamaan yang murni, dan adanya suatu perasaan khawatir akan hal-hal yang tidak diinginkan atau akan datangnya malapetaka bila tidak diadakan (Koentjaraningrat, 1984: 347).

Upacara seblang di Desa Oleshsari diyakini masyarakat sebagai upacara yang keramat. Hal ini juga bisa diamati dari proses awal dalam penentuan segala sesuatu yang berkaitan dengan waktu, tempat, pelaku maupun prasarana upacara. Berkaitan dengan pelaku upacara, khususnya penari, getaran emosi keramat sangat terasa ketika sang dukun dan keluarga seblang serta tokoh masyarakat melakukan dialog dengan orang yang kejiman (trance, kepileng-Using) yang diyakini sebagai mediator dengan makhluk halus. Mereka sangat serius, hati-hati, dan kadang ada rasa takut dalam berdialog dengannya. Demikian juga mengenai waktu dan tempat yang diyakini akan membawa hal-hal yang tidak diinginkan bila tidak sesuai dengan keinginan mahkluk halus. 
Masyarakat Desa Olehsari mengadakan upacara bersih desa bertujuan agar seisi desa dijauhkan dari berbagai petaka yang mengancam ketenangan dan kesejahteraan masyarakat. Mereka mengharapkan agar diberi berkah, keselamatan, kesuburan tanah dan hasil panen atau usaha yang baik, dijauhkan dari hama, dijauhkan dari berbagai penyakit, dijauhkan dari kerusuhan dan berbagai macam harapan baik lainnya untuk kehidupan mereka. Harapan serupa ada pada semua tradisi selamatan desa di Banyuwangi, seperti barongan di Kemiren, kebo-keboan di Alasmalang dan juga seblang di Bakungan.

Dalam kepercayaan masyarakat, upacara ritual seblang diselenggarakan bertujuan membersihkan desa dari sesuatu yang tidak kasat mata dan gangguan yang disebabkan oleh ulah manusia. Gangguan yang disebabkan oleh manusia berupa perusakan lingkungan maupun pencurian dan kejahatan lainnya. Lebih jauh mereka meyakini bahwa apabila upacara selalu dilakukan setiap tahun, tentu hal-hal seperti perusakan lingkungan dan kejahatan-kejahatan lainnya tidak akan terjadi. Namun sebaliknya, jika upacara tidak diselenggarakan keseimbangan alam dan lingkungan akan terganggu.

Upacara seblang tampak jelas fungsinya sebagai sarana membersihkan desa dari gangguan mahluk kasar dan halus terutama dari babak keliling memutari desa. Acara ini dilaksanakan pada hari ketujuh atau pada pementasan hari terakhir. Dalam kesempatan ini penari diarak keliling desa sambil menari di jalan yang dilalui. Di tengah perjalanan, tepatnya di setiap perempatan jalan rombongan berhenti, begitu pula yang dilakukan di setiap sudut desa (antogan), rombongan berhenti untuk memberi kesempatan penari berdoa dengan caranya untuk mengusir kejahatan di tempat-tempat tersebut.

Dari penuturan beberapa budayawan, seblang berasal dari kata seblak (memukul dengan sesuatu yang lentur/lemas, seperti memakai cemeti atau belarak/lidi) artinya nyeblak untuk melepaskan segala sesuatu yang menjadi hambatan. Pada kesenian gandrung ada juga adegan yang disebut dengan seblang-seblang, pada adegan ini sang Gandrung memperagakan adegan seperti orang menyapu.

b. Pengundang Kesuburan

Budaya agraris atau segala kehidupan yang mengandalkan keberuntungan dari hasil alam masih sangat mewarnai kehidupan masyarakat Desa Olehsari. Dalam masalah pertanian, mereka masih sangat kuat dengan pola bercocok tanam secara tradisional. Artinya, pola-pola penanaman, pemeliharaan, sampai pengolahan tanah dan peralatan yang dipergunakan masih mempergunakan 
alat dan sistem tradisional, seperti untuk membajak sawah tenaga sapi masih memegang peranan penting. Begitu juga ketika panenan, ekrak (alat penuai) dan arit (sabit) masih dominan.

Dalam kehidupan yang tergantung dari hasil tanaman yang di latar belakangi pola pikir yang relatif sederhana itu mereka tidak bisa lepas dari alam lingkungannya. Ketergantungan terhadap alam atau hukum-hukum alam seperti musim hujan atau kemarau menentukan kehidupan seharihari. Selain itu, masyarakat petani pada umumnya dan petani Desa Olehsari khususnya, sangat percaya adanya kekuatan-kekuatan alam atau gaib yang dapat mempengaruhi lingkungannya. Sehubungan dengan itu, wajar jika masyarakat mendambakan kesuburan dalam pertanian maupun ketentraman dan ketenangan di bidang yang lainnya. Untuk mencapai kesuburan tersebut, masyarakat petani tradisional di Desa Olehsari mengusahakan dengan penuh ketekunan, baik yang berhubungan dengan dunia rasional maupun kepercayaan. Usaha yang secara rasional telah mereka lakukan dalam kegiatan sehari-hari, sedangkan yang bersifat kepercayaan dilakukan pada waktu tertentu di antaranya dengan selamatan.

Salah satu selamatan yang telah mengakar sejak dulu sampai sekarang pada masyarakat Desa Olehsari adalah upacara seblang ini. Dengan melaksanakan ritual ini, harapan mengenai kesuburan diungkapkan lewat simbol-simbol atau barang perlengkapan yang menjadi uba rampe pelaksanaan upacara. Bendabenda itu diwujudkan dengan sesaji berupa para bungkil yang digantungkan di tarub selama upacara berlangsung. Simbol atau benda-benda para bungkil terdiri dari berbagai jenis tanaman, buah-buahan, bunga-bungaan, sayur-mayur dan lain sebagainya. Melalui representasi hasil pertanian dengan sesaji para bungkil itu masyarakat berharap agar yang ditanam menjadi subur, aman dari hama dan bisa memetik hasilnya dengan melimpah, sehingga bisa mencukupi kebutuhan sehari-hari.

Dengan media seblang yang menari dalam keaadaan trance, mereka percaya bahwa para bungkil tersebut akan memiliki kekuatan gaib yang datang dari roh halus. Karena itu, pada akhir acara ritual, sajen para bungkil tersebut menjadi barang yang diperebutkan para pelaku dan penonton. Dalam keyakinan mereka, apa yang dapat diambil dari para bungkil itu akan dijadikan tumbal atau melindungi tanaman agar subur dan selamat dari hama. Itulah salah satu yang menjadi keyakinan atau kepercayaan masyarakat dalam ritual seblang yang berkaitan dengan keberhasilan pertanian. 
Selain masalah pertanian, ada juga yang minta bunga yang memang disediakan secara khusus pada adegan kembang dirma, dan lebih ampuh lagi, dalam pandangan mereka, bunga yang menempel menghiasi omprok (mahkota) penari dapat dipergunakan sebagai syarat agar pekerjaan lancar dan sukses. Dikalangan anak muda, baik laki-laki maupun perempuan, bunga-bunga yang didapatkan bisa dijadikan pelet untuk memikat calon pasangannya. Lebih seru lagi, di akhir acara para penonton yang terdiri dari berbagai unsur dan status sosial saling berebut berusaha mendapatkan sesaji yang menggantung di para bungkil, demikian juga mereka berebut omprok untuk mendapatkan bunga-bunga yang ditempelkan di atasnya.

c. Sarana Pengobatan Penyakit

Kesenian seblang bagi masyarakat Desa Olehsari dan sekitarnya berfungsi juga sebagai sarana pengobatan. Aspek ini dapat disaksikan saat upacara berlangsung, tepatnya pada bagian awal setelah penari memperagakan beberapa adegan gendhing-gendhing, yaitu saat penari istirahat atau duduk di kursi. Pada kesempatan itu para penonton dan para pelaku satu demi satu menyodorkan gelas berisi air lewat pendamping kepada penari. Gelas-gelas itu diterima oleh pendamping yang kemudian diberikan kepada penari sambil membisikkan sesuatu ke telinganya. Bisikan itu, menurut si pendamping menginformasikan nama anak atau orang yang sakit dan juga jenis penyakit yang di derita. Penari menunduk sejenak dengan memegang gelas yang berisi air. Setelah itu si seblang memetik daun pisang muda atau bunga yang ada di omprok untuk dimasukkan ke dalam gelas, baru kemudian diserahkan kembali kepada yang meminta. Adapun cara pengobatannya, air tersebut diminumkan kepada penderita atau dioleskan pada bagian tubuh yang sakit.

Selain pada saat upacara berlangsung, upacara siraman yang dilakukan pada hari kedelapan, yaitu satu hari setelah acara selesai juga merupakan sarana pengobatan atau penyembuhan bagi masyarakat. Seringkali air bekas siraman dihimpun lalu dikemas dalam wadah berupa ember atau botol. Dari keterangan yang berhasil di dapat penulis, air tersebut akan dipergunakan sebagai obat dari berbagai penyakit, juga ada yang akan menuangkannya sedikit di sawah sebagai sarana mengundang kesuburan dan menolak balak yang berwujud hama.

d. Penghormatan Leluhur

Upacara seblang yang penuh dengan nuansa magis merupakan 
perwujudan atau realisasi penghormatan masyarakat kepada roh leluhurnya. Perwujudan ini dapat diamati pada sajian tarinya ketika mubeng desa (keliling) pada hari terakhir. Pada prosesi dari pusat upacara penari diikuti oleh para pesinden, penabuh dan masyarakat dengan dipimpin sang dukun pengutug berjalan mengelilingi desa. Setelah mereka melakukan upacara di balai desa, para pelaku melanjutkan ke makam, yaitu tempat di makamkannya leluhur masyarakat Desa Olehsari. Leluhur yang dikunjungi itu bernama Mbah Bisu. Di tempat ini, penari menunjukkan perilaku yang berbeda dari biasanya. Penari yang biasanya lincah dan dinamis pada kesempatan ini duduk dan bersujud. Suasana wingit dan angker sangat terasa, apalagi diiringi suara gendhing pesinden yang lembut mengalunkan gendhing layar kumendung. Penari pada kesempatan ini dengan dipandu pendamping dan dukun menaburkan bunga di atas makam leluhur itu di tengah kepulan asap dupa. Suasana menjadi semakin hening dan terkesan haru ketika penari menundukkan kepala dengan tangan memegang batu nisan, sebagai ungkapan bakti dan hormat kepadanya (www.banyuwangi.eastjava.com, 25 Agustus 2010).

Melihat gerak-gerik penari seblang di makam pada upacara hari terakhir ini, menunjukkan bahwa orang yang telah meninggal adalah orang yang sangat berjasa, karenanya harus dihormati. Lebih dari itu, dalam kepercayaan masyarakat, ia dan keturunannya masih berpengaruh dan bisa menyaksikan apa yang masyarakat lakukan terhadap dirinya saat ini (Zaehner, 2004: 111). Dengan demikian dapat dipahami ritual ini berfungsi sebagai sarana pengekspresian rasa hormat masyarakat kepada leluhurnya. Uraian di atas juga dijelaskan oleh Murgiyanto dan Munardi sebagai berikut :

Masyarakat sangat menghormati roh cikal bakal, dan menganggap roh itu masih berpengaruh terhadap desanya. Segala peristiwa yang menyangkut perkembangan serta perubahan-perubahan di desa tersebut, harus selalu mendapatkan perkenan atau diketahui oleh sang cikal bakal. Kelalaian penghormatan kepadanya dapat mengganggu kesejahteraan dan kedamaiaan masyarakat yang bersangkutan.

Memang dalam kepercayaan masyarakat Desa Olehsari ada anggapan bahwa orang yang telah meninggal, rohnya masih hidup bersama dengan anak cucunya yang masih hidup. Roh nenek moyang itu akan jangkungi, artinya merestui anak cucunya manakala mereka mematuhi perintah dan petunjuk-petunjuk yang diberikan ketika nenek moyangnya masih hidup. Sebaliknya, roh-roh tersebut akan marah jika mereka tidak mematuhi dan 
enggan menjalankan anjurannya.

e. Hiburan Roh Halus

Di tengah kesibukan di lapangan untuk melakukan pengamatan terlibat dalam persiapan-persiapan upacara ritual tahunan seblang ini, penulis sempat datang menemui seorang tokoh yang kebetulan juga sebagai pengurus Ta'mir Masjid Desa Olehsari. Ketika ditanya hal-ihwal seblang di Desanya dia menjelaskan:

Seblang itu adalah sarana hiburan mahkluk halus (jin). Jin itu sama dengan kita membutuhkan hiburan untuk melepaskan kepenatannya. Sebagai orang Islam, kalau kita tidak percaya kepada jin itu keliru, sebab al Quran secara terang-terangan mengisahkan ketertarikan segolongan kaum dari mahkluk halus tersebut kepada lantunan al Quran Nabi (Al Quran, 72: 1).

Mishar, nama pengurus tersebut bukanlah pendukung seblang, apalagi percaya mempunyai kekuatan-kekuatan magis yang sakral. Meskipun demikian, dia tetap menghormati upacara itu sebagai warisan leluhur yang perlu dijaga, apalagi seblang telah menjadi komoditas pariwisata. Ia yakin suatu saat kepercayaan itu akan hilang seiring dengan meningkatnya kualitas sumber daya manusia dan pendidikan keagamaan masyarakat. Secara sosiologis, agama yang dianut masyarakat satu agama memang berbeda dengan agama masyarakat yang multi agama. Demikian pula di Desa Olehsari ini, keislaman seseorang harus dipahami dalam perspektif yang berbeda dengan keislaman di masyarakat lain. Demikian cara memahami pemikiran Mishar (Askari, 2003: 11).

Pada sisi yang lain, sebagian pendukung setia upacara Seblang, mengemukakan bahwa ritual itu selain disaksikan oleh manusia biasa juga dihadiri oleh manusia halus (dirawuhi tiyang alus). Tiyang alus tersebut menurut mereka adalah leluhur keluarga seblang maupun yang mbaureksa Desa serta roh cikal bakal. Mereka itu di antaranya bernama: Saridin, Aji, Angring, Jalil, Sayu Sarinah, Mbah Bisu, dan Buyut Cili. Hal ini juga dijelaskan oleh Saleh, bahkan tiyang alus yang datang (rawuh), juga berasal dari beberapa tempat, seperti dari daerah pegunungan, lautan, dan dari hutan. Namun Saleh tidak bisa memberi keterangan lebih lanjut tentang nama-nama dari tiyang alus tersebut. Selain itu ia juga tidak bisa memberi keterangan dari hutan mana, dan dari pegunungan mana (Saleh, Wawancara: 15 September 2010).

Penjelasan di atas memang tidak masuk akal dan sulit untuk dibuktikan kebenarannya. Namun jika kita telusuri tentang fungsi tari di pulau Bali, 
masyarakatnya juga mempercayai bahwa kelompok tari Bebali yang dipentaskan di Pura Jaba Tengah berfungsi untuk menghibur para dewa yang hadir dan tamu terkemuka. Selain itu, kategori genre seni pertunjukan yang sakral yaitu wali, disajikan khusus untuk persembahan para dewa. Salah satu contoh tarian itu adalah tari rejang. Tarian ini merupakan bagian dari prosesi memandikan patung kayu (pratima) ketika dewa-dewa datang dan bersemayam di dalam pratima tersebut. Kemudian para penari menyajikan tari rejang untuk menghibur para dewa yang hadir di tempat itu.

Kepercayaan yang serupa juga ditemui pada tradisi keraton Yogyakarta dengan tarian budaya semang-nya. Tarian ini sebagai simbol kekeramatan hubungan gaib antara Sultan Agung (perintis Dinasti Mataram) dengan kanjeng Ratu Kidul. Ketika tari diperagakan diyakini ratu hadir dan menyaksikan. Bahkan di masa sekarang, di era yang modern dan rasional ini, masih ada yang mengira hubungan itu tetap terjalin antara keturunan Kanjeng Sultan dengan Ratu Rara Kidul. Karena itu, tari budaya semang juga tetap lestari.

Menyimak bentuk pertunjukan tari wali dan bebali di Bali, maupun Bedaya Semang di Yogyakarta, keduanya berfungsi sebagai hiburan para dewa dan makhluk halus, tidak jauh berbeda dengan tari seblang yang juga berfungsi menghibur roh halus dan roh leluhur. Dengan demikian tari seblang di Desa Olehsari, Banyuwangi, tari wali dan bebali di Bali maupun tari bedaya semang di Yogyakarta ditujukan untuk menghibur sesuatu yang tidak kasat mata (Suyono, 2009: 107-109). Ayu Sutarto menyebut ciri tari yang masuk kategori hiburan makhluk halus adalah gerakannya yang monoton. Seblang menari dalam keadaan intrance dan gerakannya hanya menggoyang-goyang tubuh dan kepala ke kiri dan ke kanan, sambil sesekali berputar mengelilingi para penabuh yang berada di bawah payung agung.

\section{Makna Selamatan}

Masyarakat Jawa sebagai komunitas yang telah terislamkan memang memeluk agama Islam. Namum dalam praktiknya, pola-pola keberagamaan mereka tidak jauh dari pengaruh unsur keyakinan dan kepercayaan pra-Islam, yakni keyakinan animisme-dinamisme dan Hindu-Budha (Simuh, 2002: 111). Di antara sekian banyak budaya pra-Islam yang masih melekat dan bisa disaksikan dalam kehidupan keberagamaan masyarakat Using adalah pemujaan terhadap roh nenek moyang (first-founding ancestors). Pendewaan atau mitos terhadap roh nenek moyang ini melahirkan pemujaan tertentu kepada nenek moyang 
yang mendorong munculnya pola-pola relasi hukum adat dengan unsur-unsur keagamaan (Simuh, 2002: 117). Salah satu adat istiadat, sebagai ritual keagamaan yang paling populer di dalam masyarakat Islam Jawa itu adalah selamatan atau kenduri, yaitu upacara ritual komunal yang telah mentradisi dikalangan masyarakat Islam Jawa (Hilmi, 1994: 41).

Selamatan diadakan untuk suatu peristiwa yang penting dalam perjalanan hidup seseorang. Peristiwa tersebut seperti kelahiran, kematian, pernikahan, membangun rumah, permulaan bajak sawah atau panenan, sunatan (khitan), perayaan hari besar, dan masih banyak lagi peristiwa yang dihiasi dengan tradisi selamatan. Selamatan diyakini sebagai sarana spiritual yang mampu mengatasi segala bentuk krisis yang melanda serta bisa mendatangkan berkah bagi mereka yang menyelenggarakan. Adapun objek yang dijadikan sarana pemujaan dalam selamatan ketika masyarakat belum mengenal Islam adalah roh nenek moyang yang dianggap memiliki kekuatan magis. Di samping itu, selamatan ini juga sebagai sarana mengagungkan, menghormati, dan memperingati roh leluhur, yaitu para nenek moyang (Kamajaya, 1995: 247).

Sebelum mendiskusikan selamatan secara lebih rinci, perlu diperhatikan bahwa berbagai istilah yang dipergunakan untuk menyebut ritual ini tidak sinonim, setidaknya di masyarakat Using. Selamatan adalah ritus bagi mereka yang hidup, sedangkan ngirim duwa (baca duwo-kirim doa) atau sedekah diperuntukkan bagi mereka yang sudah meninggal. Keduanya dapat digabungkan tetapi secara konseptual terpisah dan status dalam keseluruhan kompleks sinkretis berbeda. Orang dapat mengatakan selamatan itu Jawa sedekah itu Islami, namun ini hanya antisipasi.

Secara umum, tujuan selamatan adalah untuk menciptakan keadaan sejahtera, aman dan bebas dari gangguan makhluk yang nyata (kasar) dan juga makhluk halus (suatu keadaan yang disebut selamet). Walaupun kata selamet dapat digunakan untuk orang yang sudah meninggal (dalam pengertian diselamatkan), ada yang mengatakan bahwa kata selamatan tidak layak digunakan dalam upacara pemakaman, dan menggunakannya berarti keliru (Timbul, Wawancara: 17 September 2010).

Alasan utama penyelenggaraan selamatan meliputi perayaan siklus hidup, menempati rumah baru, panenan, dalam rangka memulihkan harmoni setelah perselisihan suami-istri atau dengan tetangga, untuk menangkal akibat mimpi buruk, dan yang paling umum memenuhi nazar atau janji, misalnya bernazar akan menyelenggarakan selamatan kalau anaknya sembuh dari sakit. Tetapi 
tidak ada alasan yang lebih kuat daripada keinginan mencapai keadaan yang aman dan sejahtera.

Pemaknaan terhadap selamatan yang sudah memiliki formulasi tertentu dalam sambutan-sambutan pendahuluan acaranya menyelimuti posisi dan motivasi yang beraneka ragam. Dari sini ada dua titik garis ekstrim, yakni mistikal dan santri dengan mayoritas terletak di antara keduanya. Adalah kaum mistik yang bergerak lebih jauh dalam mengembangkan gagasan dan penerjemahan yang berkenaan dengan simbol-simbol dalam selamatan.

Di sini akan diberikan contoh singkat yang berkaitan dengan simbolisme. Dalam pengajaran sekte, Adam dan Hawa atau laki-laki dan perempuan, masing-masing memberikan empat hal dalam konsepsi. Dari ayah bersumber empat unsur putih, dari ibu unsur merah. Akan tetapi setiap perilaku seks tidak selalu menghasilkan kehamilan, agar hidup terus berlangsung, harus ada unsur pelantar ketiga yang kreatif, suatu katalis, dan inilah Tuhan. Golongan mistik mengacu pada kontributor ketiga ini dengan istilah yang bervariasi: yang bersembunyi (gaib), sumber kehidupan (urip), Wisnu (Vishnu), atau kekuasaan (kwasa atau kuwasa). Dualisme merah dan putih kemudian melibatkan unsur ketiga, menjadi trinitas, Adam, Hawa, dan Wisnu. Unsur ketiga dari trinitas ini, yakni Wisnu adalah hasil dari proses saling mempengaruhi empat unsur, yakni tanah, angin, api dan air, dan unsur ini secara berkesinambungan terusmenurus saling mempengaruhi dan memelihara kehidupan. Ketiga pelantar penciptaan, Adam, Hawa, dan Wisnu, masing-masing terdiri dari empat unsur lagi sehingga menjadi dua belas, suatu kompleks yang menyerupai susunan empat-lima macam bubur berwarna-warni. Bagi sekte, gambaran dua belas menunjukkan konsep sentral bagi semua mistisme Jawa, sebagaimana terkandung dalam kalimat sangkan paraning dumadi: asal muasal dan tujuan dari yang ada (Beatty, 2001: 54).

Teknik eksplanasi yang lain adalah permainan kata yang disebut kirata basa. Di sini orang mengambil kata-kata tertentu atau suku kata tertentu dan membangun sebuah etimologi atau menemukan dalam skema pikiran orang lain kata kunci yang mengandung persamaan bunyi akhiran. Kata tersebut kemudian diambil untuk mendapatkan kata inti. Satu contoh yang sudah diberikan adalah nabi. Suku kata keduanya -bi ditemukan dalam kata bibit, sehingga nabi berarti bibit. Sego golong (nasi dalam bungkusan daun pisang yang lipatan sebelahnya dibiarkan terbuka), berasosiasi bolong, artinya lubang sehingga biasanya diartikan sembilan lubang pada tubuh (nine orifices) yang 
kesemuanya perlu dijaga. Waliyullah, wali atau kekasih Tuhan bersajak dengan kata "polah", berarti bertindak atau berbuat sesuai dengan sistem etika yang mereka ajarkan. "Pecel Pitik" yang dilakukan, dikerjakan sehari-hari (ocel-ocel) mendapatkan kebaikan (nemuo apik).

Sebagian dari permainan kata-kata ini dikenal luas meskipun agak rumit dan dapat mengundang diskusi yang berkepanjangan. Contoh lain, kata "manungsa", berarti manunggal ing rasa: berarti menjadi satu dalam perasaan. Dengan kata lain, semua orang sama pada tingkat rasa. Lebih jauh lagi, semua orang bersatu dalam "rasa ketuhanan yang abadi". Suatu maqam yang tertinggi dalam terminologi sufisme falsafi.

Selamatan memang terdiri dari makna-makna yang berbeda dan itu semua adalah persoalan interpretasi. Seperti dikemukakan oleh banyak sosiolog bahwa masyarakat Jawa memeringkat segala sesuatu, termasuk pemahamanpemahaman atas dasar skala dari yang kasar hingga yang halus, dari lapisan paling luar hingga lapisan paling dalam (batin). Makna suatu simbol tergantung pada tingkat strategi apa seseorang menggunakannya dalam pembicaraan. Suatu penjelasan mengenai tindakan fisik, seperti postur ketika bersembahyang, dalam konteks kasar atau tampak luar sebagai pemenuhan kewajiban spiritual tertentu. Pemaknaan itu tidak salah, akan tetapi ia mengandung kebenaran yang lebih mendalam jika dapat ditunjukkan melalui teknik-teknik interpretasi tertentu.

Para santri biasanya merelatifkan pengetahuan orang Jawa hanya sekadar adat, sedangkan golongan mistik kadang-kadang mengacu kepada tingkat-tingkat kesufian. Pengetahuan yang melekat pada tahap akhir, gnosis barangkali begitu jauh berjarak dari tahap pertama yang tampak kontradiksi dengannya. Akan tetapi, pengetahuan esoteris tidak pernah dibawa ke dalam perbandingan terbuka dengan pengetahuan biasa kecuali dikalangan ahlinya.

Akhirnya, penulis merasa perlu menyimpulkan secara praktis mengenai soal selamatan ini agar tidak terjebak pada perdebatan panjang yang bertumpu pada simbol-simbol, tetapi menarik signifikansi sosial selamatan yang berbeda dari makna simboliknya. Dalam hal ini, penyelenggaraan selamatan memiliki kegunaan lebih luas, antara lain meningkatkan tali silaturahmi, rasa persaudaraan dan rukun di antara tetangga, saudara atau pekerja (di sawah dan ketika mendirikan rumah). Memang rukun yang berarti harmoni sosial dan ketentraman serta ketenangan bersama merupakan nilai sosial yang amat penting dalam kehidupan masyarakat desa. Disamping itu, lestarinya selamatan ini memberi makna bahwa masyarakat masih komitmen terhadap budayanya. 
Selamatan juga memberi efek psikologis dalam bentuk keseimbangan emosional pelaku secara khusus dan juga seluruh partisipan yang hadir pada umumnya.

Dengan demikian selamatan bukan sekedar pesta makan untuk menunjukkan gengsi tertentu di mata masyarakat, melainkan wujud rasa syukur atas karunia Yang Maha Kuasa dan harapan untuk selalu berada dalam lindungan dan rahmat-Nya. Tidak ada yang salah secara teologis dalam selamatan, karena ia selalu diawali dengan permohonan kepada Allah Yang Maha Kuasa dan lantunan doa yang ma'tsur. Demikian juga mungkin pada sedekahan yang diistilahkan dengan ngirim duwa bagi para ahli waris (keluarga) yang diperuntukkan bagi orang yang telah meninggal. Meskipun kaum muslim berbeda dalam menanggapi persoalan selamatan ini, tapi yang jelas ada landasan skriptural untuk mengatakan bahwa hal tersebut tidak menyalahi semangat syari'ah Islam.

\section{Simpulan}

Sebagai bangsa yang plural Indonesia memiliki dua macam sistem budaya, sistem budaya nasional dan sistem budaya etnik lokal. Sistem budaya nasional relatif baru dan masih terus dalam proses pembentukan. Sistem ini berlaku secara umum untuk seluruh bangsa Indonesia, tetapi sekaligus berada di luar ikatan budaya etnik lokal yang manapun. Nilai-nilai tersebut menjadi bercitra rasa Indonesia karena dipadu dengan nilai-nilai lain yang sesungguhnya di derivasi dari nilai-nilai budaya lama yang terdapat dalam berbagai sistem budaya lokal. Sistem budaya lokal, atau disebut juga kearifan lokal pada dasarnya merupakan landasan bagi pembentukan jati diri bangsa secara nasional. Kearifan lokal itulah yang akan membuat suatu budaya bangsa memiliki akar kuat.

Kearifan lokal atau local wisdom lahir dari proses panjang yang dibimbing oleh nilai yang diyakini secara kolektif kebenarannya berupa kepercayaan atau agama. Kepercayaan itu kemudian, oleh watak omnipresentnya hadir di manamana, ikut mempengaruhi bahkan membentuk struktur sosial, budaya, ekonomi dan juga politik. Di dalam sistem sosial budaya masyarakat Desa Olehsari atau Using pada umumnya, kearifan itu menjelma dalam nilai dasar rukun yang menjadi falsafah hidup masyarakat. Nilai itu tidak diragukan berasal dari ajaran agama atau kepercayaan yang dianut masyarakat, di samping juga dari sistem etika sosial yang diwarisi secara turun-temurun.

Kerukunan juga terwujud dalam pelaksanaan upacara budaya seblang. Sebagai ritual budaya tahunan, seblang sebenarnya tampak sebagai tradisi yang 
penuh ambiguitas. Melihat tata fisik arena dan penyajian tari dengan segala asesoris yang menempel, juga sesaji-sesaji yang disuguhkan atau dipasang di bawah tarub sebagai para bungkil, mirip dengan tradisi kasada yang dilaksanakan tahunan oleh suku Hindu Tengger, padahal penduduk sekitar memeluk Islam. Inilah manifestasi dari falsafah kerukunan yang menjadi inti tradisi dan budaya masyarakat Using Desa Olehsari di Banyuwangi. Prosesi budaya ini ditutup dengan upacara yang disebut Ider Bumi, yaitu seluruh masyarakat dipimpin oleh sesepuh Desa mengelilingi perbatasan Desa Olehsari dengan membaca sholawat dan takbir. Bermula dan diakhiri di depan masjid kemudian secara bersama-sama menuju balai dusun untuk melaksanakan kenduri memohon keselamatan dengan tata cara Islami bagi desa dan seluruh warganya.

Kearifan lokal lain yang saat ini mulai tampak menjadi sistem budaya nasional adalah selamatan atau kenduri. Selamatan adalah ritual komunal yang telah mentradisi di kalangan masyarakat Islam Desa Olehsari, demikian juga masyarakat Islam Jawa. Selamatan dilaksanakan untuk menandai sebuah peristiwa penting dalam kehidupan seseorang seperti kelahiran, kematian, pernikahan, membangun rumah, permulaan membajak sawah atau pasca panen, sunatan, perayaan hari besar, dan masih banyak lagi peristiwa-peristiwa yang diiringi dengan tradisi selamatan.

Pemaknaan sederhana pada selamatan di antaranya adalah agar "wong nemu selamet" dalam beraktivitas atau bekerja apa saja. Yang bertani tanamannya aman dan panennya melimpah, yang berdagang sukses dan lancar dengan hasil yang memuaskan. Intinya segala jerih upaya untuk niat kebaikan mendapat perkenan Gusti Allah Yang Maha Kuasa. Di dalam selamatan tersaji "pecel pitik", yaitu ayam bakar yang dibumbu santan dengan menyertakan parutan kelapa yang disebut ampas. Dalam permainan bahasa (kirata basa-Jawa), maksud disajikan pecel pitik adalah supaya "kang diucel-ucel neтио apik" yaitu semua yang dilakukan berakhir dengan mendapatkan kebaikan tanpa hambatan yang berarti yaitu kemaslahatan.

\section{Daftar Pustaka}

Askari, Hasan. 2003. Lintas Iman Dialog Spiritual. Terjemahan oleh Sunarwoto. Yogyakarta: LKiS.

Beatty, Andrew. 2001. Variasi Agama di Jawa. Jakarta: RajaGrafindo Persada.

Hilmi, Masdar. 1994. Islam and Javanese Aculturation. Canada: Thesis Magister 
of McGill University.

Kamajaya, Harkono. 1995. Kebudayaan Jawa: Perpaduan dengan Islam. Yogyakarta: Ikatan Penerbit Indonesia.

Koentjaraningrat. 1984. Kebudayaan Jawa. Jakarta: Balai Pustaka.

Muthahhari, Murtadha. 2007. Manusia dan Agama Membumikan Kitab Suci. Bandung: Mizan.

Rahmat, Jalaluddin. 2005. Psikologi Agama. Bandung: Mizan.

Saleh. Hasil Wawancara. 14 September 2010

Saleh. Hasil Wawancara. 15 September 2010

Saleh. Hasil Wawancara. 17 September 2010

Shihab, Quraish. 1997. Wawasan Al Quran. Bandung: Mizan.

Simuh. 1989. Mistik Islam Kejawen Raden Ngabehi Rangga Warsita. Jakarta: UI-Press.

Simuh. 2002. Sufisme Jawa: Transformasi Tasawuf Islam ke Mistik Jawa. Yogyakarta: Bentang.

Suyono, Capt. R.P. 2009. Ajaran Rahasia Orang Jawa. Yogyakarta: LKis.

Sutarto, Ayu. 2006. Sekilas Tentang Masyarakat Using. Makalah pada Pembekalan Jelajah Budaya di Balai Kajian Budaya dan Nilai Tradisional Yogyakarta.

Veeger, K.J. 1993. Realitas Sosial. Jakarta: Gramedia.

www. banyuwangi.eastjava.com. Diakses 25 Agustus 2010

Zaehner, R.C. 2004. Mistisisme Hindu Muslim. Terjemahan oleh Suhadi. Yogyakarta: LKiS. 